\section{Emeritus Professor PSS Panditharatne}

Sobitha Sanjaya Panditharatna, Professor Emeritus of Anatomy, died recently from cerebral haemorrhage. Scholar, educationist, man of vision, teacher, and researcher, Professor Panditharatne had his early education at leading Buddhist schools in Ceylon, Dharmaraja College and Ananda College. This instilled in him the Buddhist traditions of compassion and fairness.

He entered the Faculty of Medicine, of the University of Ceylon in 1953, graduated MBBS in 1959, completing all the examinations with Honours. Following his house appointments at the General Hospital in Galle, he joined the Department of Anatomy as a demonstrator in 1962, and became a lecturer a year later, after passing the primary FRCS (England).

Dr. Panditharatne came under the influence of Professor GAG Mitchel, Neuroanatomist of international repute, who directed his research on cranial nerves. He was awarded the $\mathrm{PhD}$ from the University of Manchester in 1967 and returned to Ceylon, to be appointed Senior Lecturer in Anatomy at the Colombo Medical Faculty. He was next elevated to the Chair as Professor of Anatomy and Head of the Department, Faculty of Medicine, University of Colombo. He held this position for 22 years, retiring in 1998 as Senior Professor. In recognition of his services to medical education, he was awarded the Emeritus Professorship by the University.

He faced many challenges with the introduction of the new medical school curriculum, and restructured it, devoting more time and effort to fundamental principles, and pioneered the introduction of MCQs to objectively assess the knowledge of students. A much sought-after teacher in basic sciences, Professor Panditharatne, was an examiner for MS Surgery Part I and the MS Dental Surgery Part I for decades. In recognition of his contribution to surgical education, the College of Surgeons of Sri Lanka awarded him the Honorary Fellowship of the College in 1989.

His skilled hands made him an excellent prosector, which led to the birth of the human anatomy museum. He dissected, mounted and labelled over two hundred human body parts for self-study. This centre is on par with the anatomy museum of the Royal College of Surgeons of England.

Professor Panditharatne held responsible positions, as Chairman of the Curriculum Development and Evaluation Committee of the Faculty, Member of the Standing Committee of the Medical and Dental Sciences of the University Grants Commission, Member of the Senate, University of Colombo, Member of Sri Lanka Association for the Advancement of Science, and was acting Dean, Faculty of Medicine, Colombo, on many occasions.

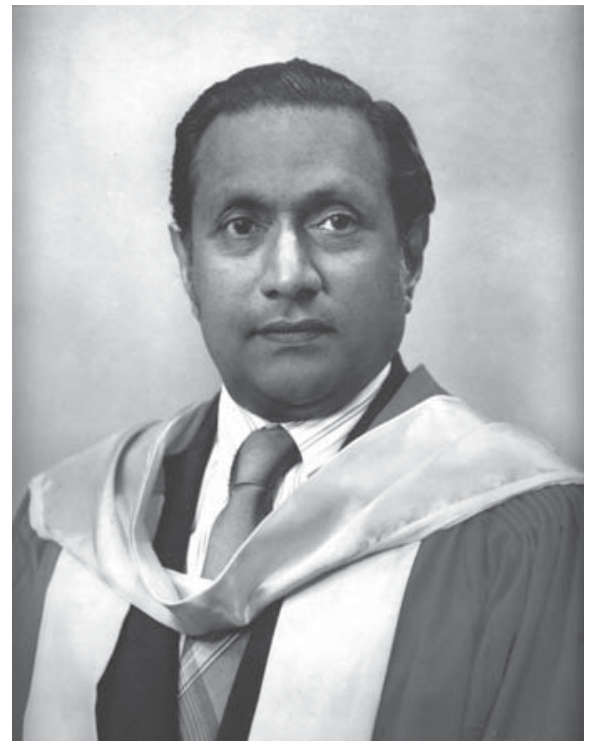

Apart from his commitment to the University, Professor Panditharatne was invited to be the Registrar of the Sri Lanka Medical Council, at a time when the need for reorganisation and modernisation was long overdue. He was the Registrar of the SLMC, for a total of 11 years and relinquished the post due to ill health. He implemented many progressive changes in the method of registration of local and foreign medical graduates and other personnel in paramedical disciplines.

A remarkable personality, his appearance was rugged and stern, often masking the kindness beneath. He inspired the academic and non-academic staff of the Department of Anatomy to work as a team. He was mentor, advisor, colleague, and role model to all of us. Even after his retirement, he shared our joys as we celebrated birthdays, anniversaries, successes and promotions. He won the admiration of his colleagues and students.

It was traditional to celebrate his birthday in the Department. Unfortunately, this did not materialise this year due to his ill health. However, none wished to miss the event, and the entire staff of the Anatomy held the felicitation at his residence on the 21st of April with his wife Manel, children and grandchildren. It was an enjoyable event, but was to be our last meeting with him. He died on the 2 September 2005.

He has left us a legacy of unity and service to others.

Benitta E Stephen, Professor Department of Anatomy, Faculty of Medicine, University of Colombo, Sri Lanka. 